\title{
Greeks' Identities in Smyrna, 19th - 20th Century Local and Global Parameters
}

\author{
Evangelia Boubougiatzi ${ }^{1}$, Ifigenia Vamvakidou ${ }^{1} \&$ Argyris Kyridis $^{2}$ \\ ${ }^{1}$ University of Western Macedonia, Greece \\ ${ }^{2}$ Aristotle University of Thessaloniki, Greece \\ Correspondence: Ifigeneia Vamvakidou, School of Pedagogics, Department of Nursery Education, University of \\ Western Macedonia, Florina, 53100, Greece. Tel: 30-2385-55-103. E-mail: ibambak@uowm.gr
}

Received: December 26, 2012 Accepted: February 22, 2013 Online Published: February 26, 2013

doi:10.5539/res.v5n1p124

URL: http://dx.doi.org/10.5539/res.v5n1p124

\begin{abstract}
In this research we pose an historic question about the Greek identities that have been grown and excelled in Smyrna, in the late of 19th-20th century. The basic elements for the construction of the Greek identity were the orthodox Christian religion, the language, the origins from ancient times, and the education. The awakening of the Greek national consciousness in the years of the Ottoman Rule relied mainly on the use of the Greek language, as it was grow, secretly or openly, by the church.

The historical context refers to the 19th and the 20th century and we focus on the construction of the Greek Identities. The specific historic place is Smyra.

The methodology that we use is the historic qualitative analysis of historic archives. We assume that the factors that compromise the Greek identity come from the religion, the education, the ethnicity, the culture, the citizenship, the locality and the relations with the other population they lived with.
\end{abstract}

Keywords: nationality, identities, citizenship

\section{Introduction}

The identity of the Greeks of Smyrna (Ismir) is studied through the contrast of the image they had of themselves versus the one they had about the Ottomans, Europeans and other nationalities living in Smyrna in the late of $19^{\text {th }}-20$ th century. The historical era in this issue refers to the dissolution of the Ottoman Empire, the decisions of the Young Turks and the Kemalist governments for radical changes in order to create a net national Turkish state in 1922, until the violent expulsion of the Greek population from Asia Minor.

Smyrna was a city on the shores of western Asia Minor, which, since the 18th century, was the most important commercial port in the East. From there, in the early $20^{\text {th }}$, materials for industrial textiles (wool, cotton, silk) and agricultural products (cereals, raisins, figs, tobacco) were exported to the West Raw, worth more than 135.000.000 francs. At the same time there were imported goods worth more than 120.000.000 (Issawi, 1980: 188; Kontogiannis, 1995: 302-304). The growth has brought diverse populations in the region, resulting Smyrna, in the early 20th century, to become a multicultural society with Greeks, Ottomans, Armenians, Jews, Europeans and Levantines (Notaras, 1972: 13, 23). In that society Greeks had the dominant position, both in a demographic and economic level (Panayotopoulos, 1983: 87-128).

The Ottomans' tolerance of the monotheistic religions, in specific of the peoples of the Bible, as Christians and Jews, in accordance with the paragraph of the Koran (Bostom (ed.) 2005: 226; Kitromilidis, 1971: 327), gave privileges to the Greeks of the Ottoman Empire and did not prevent Greeks to organize Greek communities and local dioceses. The Ottoman system of organization, since the 15th century, was the "millet" system, which differentiated the religious communities and accepted the Greek Orthodox Ecumenical Patriarchate, the Cathedrals and the Elders of the Greek communities, as leaders of the Greek Communities who together promoted the religious, educational and social autonomy of the Greeks (Kitromilidis, 1983: 34). Their main task was to maintain the educational institutions, the church funds, and the income from bequests and real estate, which belonged to schools or churches (Vakalopoulos, 1998: 323-324). 
The millet repealed by the proclamation of the Tanzimat reform decree, Hatti-Sheriff (1839) and Hatti-Humayun (1856) (Inalcik, 1978: 616; Inalcik, 1964: 56-57, 60-62; Lewis, 1963: 109-113; Davison, 1963: 413). These reformations gave the rights of equality to all the peoples of the Ottoman Empire. Although they removed the Patriarchate's benefits, arising from the Orthodox Christian religion, they allowed the creation of Greek Societies and educational, musicians, gymnasts, religious Fraternities. The "Hellenic Literary Society of Istanbul", the "Ministry of Education of the unredeemed Hellenism", as featured (Stavrou, 1967: 320; Mamoni, 1983-1: 291), took the responsibilities of the Ecumenical Patriarchate. They were in direct cooperation with the Ecumenical Patriarchate and with the Educational Committee, which it designated. They controlled the establishment of schools, their financial support, the publication of textbooks and other books, the appointment of the teachers, the scholarships throughout Asia Minor (Vakalopoulos, 1998: 323-324).

The Associations and the Fraternities generally cultivated the Greek identity in Asia Minor. In addition they aimed to support the intellectual culture of the Greeks, the language and the specific cultural elements, in order to keep their ancestors' identity (Mamoni, 1983-2: 63-114). The Greek Associations and Fraternities struggled for the creation of special national consciousness in the Ottoman state and for their survival versus to the homogenization and Turkification, which initiated by the Young Turks in 1908 (Soldatos, 1998: 3-6).

The "Society for the Propagation of the Greek letters" was the center of the "national struggle" in Smyrna. It was the second Society in Asia Minor, after the "Hellenic Literary Association in Istanbul", which held materially and morally to the "hellenisation" of all the Greeks, of all the social and economic status. The cooperation of Metropolitan Chrysostomos of Smyrna was crucial to the flourishing of the education and the cultivation of Greek national consciousness. The work of the Association, within the Community has always had cultural, scientific and artistic content as well as political connotations. References to classical Greece which were obvious on the names of music and educational Association - such as "Homer", "Orpheus Musical Society," "Apollo," "Hermes", "Theseus", "Pelops" - indicated the orientation towards Hellenism too (Kouroupou, 1982: 149-184; Kouroupou, 1993-1994: 235-288).

\section{The Historic Question}

The Greek identity has been grown and excelled in Smyrna in the late of the $19^{\text {th }}$-20th century. The basic elements of this identity were the orthodox Christian religion, the language, the origins from ancient times, the education. The awakening of the Greek national consciousness in the years of the Ottoman Rule relied mainly on the use of the Greek language, as it was supported by the church.

The level of education is constantly being improved in Smyrna since the founding of the "Old School", in 1708: that was the first Greek school in Smyrna. The other school was the "Evangelical School" founded in 1733 by Elders and monks from Chios. The establishment of the primary schools in all districts of the city proves the interesting for the Greek language (Anastasiadis, 1938: 9-115). The "New Public School" was founded in 1803, which later was renamed to "Philological Gymnasium".

In 1830 girls started to attend to Greek community schools, known as the "Girls' School of the Holy Fotini" and later as the "Central Girls' School". The "Homeric Girls' School" was a High School for girls, founded in 1881 to protect girls from proselytizing; there were created more than twenty private girls' schools. The foundation of girls' school reflected fully the diversity between the Greek perceptions about the position of women in the society and the girls' education versus the Ottoman beliefs about the women's position (The Archive of the Ethnomartyr from Smyrna Chrysostomos, Doc. 7, 2000: 11; Athinogenis, 1938: 137-158; Emmanouilidis, 1924: 399).

\section{The Data}

The numerous Greek newspapers had been the mass medium for the "national mission", as it was defined by the Greek journalists. 135 Greek newspapers and magazines circulated in Izmir during the period 1831 until 1922, compared to 16 Turkish, 34 Armenian, 12 Jewish, 1 Italian and 22 French-speaking, which were published by the Levantines, Greeks, Armenians and Jews (Solomonidis, 1959: 225-250). The Greeks, therefore, attached great importance to the Press for the preservation of the language and the promotion of Greek ideological, educational and cultural issues. The columnists consciously supported the civilizing penetration of Greek culture in Asia Minor.

In the Greek identity we also can find the cosmopolitan Western cultural elements. The French, British, Dutch and other Europeans who settled in Smyrna since the 16th century for commercial mainly reasons, transported their culture and their habits (Bourdieu, 1980: 75-165; Bourdieu, 1984: 613; Bourdieu, 1986: 241-258). In the 
American, German, French, educational institutions of the city, children with foreign citizenship as well as students with Ottoman citizenship, nevertheless with Greek identity, were all together students.

The European repertory theatre brought the new artistic performances which were played by Athenian drama troupes. Since the 19th century the drama education had been developed, and were created troupes by excellent indigenous actors, who shared repertory of European and Greek content (Sideris, 1990; Solomonidis, 1954).

The interaction of Greek and European, combined with the economic growth and the industrialization which was expanded, leaded to wider urbanization of the national-religious Greek community, a phenomenon which was reflected in the habits, clothing, housing, social events.

\section{The Citizenship}

The Greek-Ottoman identity of many Greeks from Asia Minor was a complicated one. They determined themselves as Greek-Ottomans, because they supported the Ottomanism reforms, which the Tanzimat had declared. The term "Greek-Otoman" was first used by the journalist Andrew Kavafaki from Constantinople,

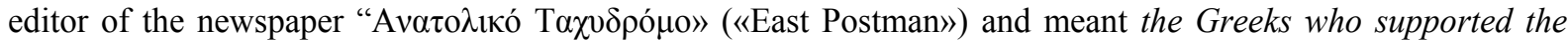
Ottomanism of the Tanzimat (The Archive of the Ethno Martyr from Smyrna Chrysostomos, by Alexandris: xiv). It was the result of the combination among the liberal promises of a short-lived Ottoman Constitution of 1876 on equal rights for all citizens regardless of religion and the plan of a peaceful coexistence and foundation of "The Eastern Federation", which had been declared by the "Organization of Constantinople". The "Organization of Constantinople" cultivated by the politicians Ion Dragoumis and Athanasios Souliotis-Nikolaidis. Although it lasted only two years, the constitution of 1876 fostered hopes for a future administration of the Ottoman government on equal terms for Christian and Muslim populations (Veremis, 1998: 61).

The supporters of the Greek-Ottoman cooperation were 1) those who had benefited from the trade with the West and from the development of industry and shipping, resulting in a financial and social comfort, 2) some bishops and new "Fanariotes" because of the benefits they had in the Ottoman state (Alexandris, 1980: 365-404). They adopted the idea of coexistence among the peoples of the East and the idea of the Greek-Ottoman leadership. In that context they accepted the plan of Dragoumis and Souliotis-Nicolaidis to create a multinational federation in which, as they anticipated, the Greek elements would soon acquire a political role, because of the excellence in literacy, education and economy.

Nevertheless a large proportion of Greeks in Smyrna was contrary to Ottomanism. They didn't believe in the promises about the representation of all the citizens in the parliament, the equality before the law, the religious freedom, the independent judiciary and the decentralization. They knew well the traditions and the requirements of the Muslim religion, which degraded the non-Muslim populations and tolerated the people of the Bible.

They were the followers of the "Great Idea", meaning the release and the integration into the national center, in the previous status of the Greeks in Macedonia, Thrace and Epirus. They alleged that the Greek state would be more viable with the new and the necessary extension of the boundaries. Indicative of these different perceptions was the fact that the conflict has been moved even within the Ecumenical Patriarchate, between Patriarch Joachim III and "anti-ioakeimikous". The cause of this contention can be described as the dichotomy among the "ethnarchy" versus the "irredentism". They argued for the definition of the national center in Istanbul and in

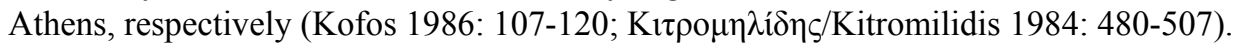

A group of Ottoman intellectuals who belonged to the new bourgeoisie (Kyridis 2005) supported the idea of a multiethnic society, however, under the rule of the Ottoman nation in order to construct an Ottoman citizenship. They thought that the reformers of the constitution were vassals of the European powers, that the measures, which would improve the position of non-Muslims, were traitors to their country, and that the indigenous Christian population was carriers of foreign interests. In this context, in 1908, the Movement of the Young Turk emerged, who rushed to enforce its policy (Inalcik, 1978; Zürcher, 1984: 117-121).

\section{Ottoman Citizens}

The primary aim for the Young Turks was to construct an ethnocentric identity of the Ottomans. The measures that were designed aimed to assimilate the non-Turkish communities to Ottomanism, in order to shape a Turkish national consciousness (Taner \& Akcam, 2007: 90-91). Therefore the multinational character of the Empire had to be disappeared because of the superiority of Islam over the others religions (Horton, 1992). The Young Turks combined the Islamic religion with nationalistic identity and citizenship versus to the multinational citizenship of the Empire (Landau 1981: 45-46). The Greek identity was the first to be lost, because, as proclaimed by the Young Turk Revolutionary Committee, Greek populations tended to attribute racial, social, ideological diversity in the Ottoman Empire. Therefore in 1910 they proposed a new institutional framework of 
schools giving priority to the abolition of the School Comities and to the Elder of the Greek Associations, who

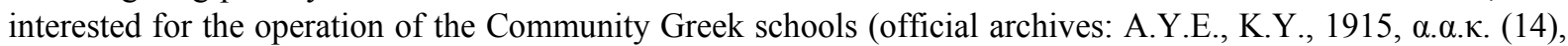
( $\chi$. Protocol n), Short historic review, Athens 24.6.1915); Persecutions of the Greek Population in Turkey since the Beginning of the European War-According to Official Reports of Hellenic Diplomatic and Consular Agents, Greek Ministry for Foreign Affairs, 1918).

\section{The Education}

The Young Turks' state took control of all the educational institutions, the community's and the private ones. The Ottoman Ministry of Education managed all the educational issues. The State had the financial security of schools and of the teachers, prohibiting the Greek Community and the Ecumenical Patriarchate to get involved in education policy (Wien, HHStA, PA, XXXVIII, Karton: 369, Konsulate, 1916, Smyrna, No 28/P, Austrian consul in Smyrna addressing the minister for foreign affairs baron St. Buriàn, Smirna 18.4.1916.). Government reduced the amount for education. Indicatively, on the recommendation of the local Ottoman authorities of the Aydin villayet, had been offered the amount of 67 Turkish lira for the operation of schools, monthly, compared to the 1.200 and more which the Greek communities used to offer for the same purpose (Wien, HHStA, PA, XXXVIII, Karton: 349, Konsulate, 1910, Smyrna, No 67, Austrian consul in Smyrna addressing count Alois Grafen von Aehrenthal, Smirna 14.10.1910; Boubougiatzi 2011 (in print). The teaching of the Turkish language became compulsory and it had to be taught at the same hours that used to be taught the classics authors, the European languages and the history (Persecutions of the Greek Population in Turkey since the Beginning of the European War-According to Official Reports of Hellenic Diplomatic and Consular Agents). The School Committees should be composed only by Ottoman citizens. The non-Ottoman citizenship teachers had been prohibited to work, with penalties directed even against their potential students (Soldatos, 1989: 125). The Government ordered to use only the Turkish language in public places and to give Turkish names to the villages and the towns, to the Christian cathedrals, even to the shops (Affari Politici, Turchia 1919-1930, Pacco 1666, N. 1817/203, Athens 5.9.1917; A.Y.E, K.Y., 1914, A/21 ع', $\sigma \tau^{\prime}$, protocol n. 539, Kapsabellis addresses Pana, Smyrna 21.2.1914). Moreover, the employers of the Companies and the members of professional unions were obliged to become Ottoman citizens, on penalty of dismissal to those who refused (A.Y.E., K.Y., 1914, A/21 $\alpha$, protocol n. 14687, 5.1914).

\section{The Marriages}

Another measure which attended to the loss of the Greek identity and of the multinational citizenship was the violent separation of the inhabitants of the same villages, even the separation of the family members. They were obliged to move from the West coast of Asia Minor to the interior for "military reasons" during the period of the World War I. The residents of a village were separated into groups of two to ten families, while the members of a family were scattered to ottoman villages under the condition that the Greek element is no more than the $10 \%$ of the total population («Persecution of Greeks Turco-German Plan», The Scotsman, 15.7.1915).

Mixed marriages were forced between Muslim men and Greek women, but also prohibited marriages with the opposite combination («Germans Inspired Turkish Atrocities against Greeks», The New York Times, 19.9.1918). The aim was the Islamization of Greek women (Night Wire A. P., «Turks Slaughter Greeks, Sell Women to Slavery», The Los Angeles Times, Los Angeles 9.6.1918; Persecutions of the Greek Population in Turkey since the Beginning of the European War-According to Official Reports of Hellenic Diplomatic and Consular Agents), but the plan did not yield the expected results because of the moral, religious and national resistance. It didn't work because of the "solution" of "kryptochristianism" (Christians in secret), which had been invented by the Greeks in order to reduce the Islamization. Finally there were established asylums for orphan boys, where also revived the old system of Janissaries. In this way the effort of annihilation of all the non-Turkish elements had been strengthened («900.000 Greeks Killed», The New York Times, New York 3.12.1918; «Turkish Cruelty bared by Greeks», The New York Times, New York 16.6.1918).

\section{The Economy}

Equally crucial blow to the Greeks of Asia Minor were the embargo measures which were taken by the Young Turk government. The measure of the "national will", meaning the abstinence of the Muslims from any trade with the Greeks, aimed to the national awakening of the Ottomans (A.Y.E., K.Y., A/21/ $\eta$ ' (without protocol n.), Chrisostomos addresses Kapsabellis, Smirna 26.5.1914; Memorandum concerning the rights and adversities for the residences in Asia Minor and Thrace 1918; Morgenthau 1929: 60). Greeks were excluded from their land during the period that they had to harvest the crops. They were not allowed to claim the money that the Muslims owned to them. They couldn't keep their professional unions (A.Y.E., K.Y., 1914, A/21 $\alpha$, protocol n. 58, Tserepis addresses Strait, Aivali 16.3.1914). They were imposed on temporary duties, beyond the heavy taxes 
which already existed. There were confiscated assets from the Greeks, which later were appropriated by the government officials. The Greek communities were weakened and gradually came the extermination of the Greek element and the forcible expulsion from Smyrna in September of 1922 (Boubougiatzi, 2011).

In this Greek-ottoman identity we can remark some notions of citizenship as:

- $\quad$ the right to cultural participation (Turner, 1993);

- the right to enter a society and then to remain within that society (Yuval-Davis, 1997);

- the relation among the local and global cultural orientation (Held 1995);

- the rights and responsibilities of the visitors to other places and cultures (Urry, 1997).

\section{Discussion Local Global}

The Greek identity remained robust in Smyrna until the last minute of the Greek presence in Asia Minor. Due to the violent persecution which suffered the Greeks during 1913-1922, they abandoned every prospect of coexistence with the Ottoman element and they wanted the union with Greece.

The local characteristics were added to the dominant Greek features associated with European culture. Those who survived the persecutions brought this culture in Greece, to give traditional and new elements to the identity and the citizenship of Greeks into the Greek state.

The presence of foreign institutions in Smyrna was accompanied by the presence of foreign missionaries and was part of the colonial policy of the United States and European countries for review and economic penetration in the region.

It was the same policy that began in the 19th century in the form of loans and investments in the Ottoman Empire.

Imperialism, the final phase of the colonial policy of European states in the 19th century, as a political theory aimed at territorial expansion, at acquisition of strategic, geographical and economical areas. Therefore they wanted to have the absolute control in the political and economic level.

The cultural and economic integration are basic signifiers of globalization. Certainly, 1922 is too early to talk about globalization, since it is a term which has been used for the first time in 1944, in Washington, by the representatives of the forty-four allies of the Second World War, during the planning of the postwar economic model (Note 1). However, in Smyrna and Asia Minor there was a financial and multi-cultural universalization by foreign bodies, with the aim of political and economic power, which can be described as a phenomenon of "early globalization".

\section{References}

Albrow, M. (1996). The Global Age. Stanford, Stanford University Press.

Alexandris, A. (1980). The Greeks in the Service of the Ottoman Empire 1850-1922. Press Release of the Historical and Ethnological Company of Greece, 23, 365-404.

Anastasiadis, A. S. (1938). The Evangelical School of Smyrna. Asia Minor Chronicles, 1, 9-115.

Appadurai, A. (1990). Disjuncture and difference in the global culture economy. Theory, Culture, and Society, 7 , 295-310.

Athinogenis, A. (1938). Educational Company and the Omirous Parthenagogeio. Asia Minor Chronicles, 1, 137-158.

Bostom, A. G. (Eds.). (2005). The Legacy of Jihad. Amherst, New York Prometheus Books.

Boubougiatzi, E. (2011). The Percecutions of the Ionian Greeks 1914-1922 (in press). Thessaloniki.

Bourdieu, P. (1980). The Logic of Practice. Stanford, Stanford University Press.

Bourdieu, P. (1984). Distinction: A Social Critique of the Judgement of Taste. London, Routledge.

Bourdieu, P. (1986). The Forms of Capital. In J. G. Richardson (Eds.), Handbook of Theory and Research for the Sociology of Education (pp. 241-258). New York, Greenwood Press.

Brunn, S. D., \& Leinbach, T. R. (Eds.). (1991). Collapsing Space and Time: Geographic Aspects of Information and Communication. New York: Harper Collins Academic.

Castells, M. (1996). The Rise of the Network Society. Blackwell. Oxford. 
Cerny, G. P. (1997). International Finance and the Erosion of Capitalist Diversity. In C. Crouch, \& W. Streeck (Eds.), Political Economy of Modern Capitalism: Mapping Convergence and Diversity. London, SAGE.

Davison, R. (1963). Reform in the Ottoman Empire 1856-1876. Princeton New Jersey.

Emmanouilidis, E. (1924). The Last Years of the Othoman Empire. Athens.

Featherstone, M., Lash, S., \& Robertson, R. (Eds.) (1995). Global Modernities. London, Sage Publications.

Gilroy, P. (1993). Small Acts: Thoughts on the Politics of Black Cultures, Serpent's Tail.

Held, D. (1995). Democracy and the Global Order. Cambridge, Polity.

Horton, G. (1992). Concerning Turkey. Diplomatic Documents of the U.S.A., Athens.

Inalcik, H. (1964). The Nature of Traditional Society. In R. Ward, \& D. Rustow (Eds.), Political Modernization in Japan and Turkey. Princeton.

Inalcik, H. (1978). Application of the Tanzimat and its Social Effects. The Ottoman Empire: Conquest, Organisation and Economy. Varorium Reprints. London.

Issawi, C. (1980). The Economic History of Turkey, 1800-1914. Chicago and London. University of Chicago Press.

Kitromilidis, P. (1983). The Greek State as National Centre. In D. Tsaousis (Eds.), Hellenism - Hellenikotita (pp. 143-164). Athens..

Kitromilidis, P. (1984). The End of the Ethnarch Tradition. Testimonies from Unpublished Letters of Chrysostomos of Smyrna to Ionas Dragoumis. Amitos in Memory of Fotis Apostolopoulou, The Centre for Asia Minor Studies (pp. 480-507). Athens.

Kitromilidis, P. (2012). The Islamization of Asia Minor and the Historical Descends of Greek - Turkish Relations. In S. Vryonis, The Decline of Medieval Hellenism in Asia Minor and the Process of Islamization from the Eleventh through the Fifteenth Century. University of California Press. Berkeley, Los Angeles and London.

Kofos, E. (1986). Patriarch Joacheim III (1878-1884) and the Irredentist Policy of the Greek State. Journal of Modern Greek Studies, IV(2), 107-120.

Kontogiannis, P. M. (1995). Geography of Asia Minor. Reprint. Athens.

Kouroupou, M. (1982). Prints References of the Asia Minor Institutes and Associations 1846-1922. Press Release the Centre for Asia Minor Studies, 3.

Kouroupou, M. (1993-1994). Prints References of the Asia Minor Institutes and Associations 1846-1922. Press Release the Centre for Asia Minor Studies, 10, 235-288.

Kyridis, A. (2005). The Transmutations of Alterity. In A. Kyridis, \& A. Andreou (Eds.), The Dual Tails of the Same Coin, Aspects of Alterity. Athens, Typothito.

Landau, J. (1981). Pan-turkism in Turkey. A Study of Irredentism. London.

Landau, J. (1995). Pan-turkism. From Irredentism to Cooperation. Indianapolis.

Lash, S. \& Urry, J. (1994), Economies of Signs and Space (Theory, Culture \& Society). London, Sage Publications.

Lewis, B. (1963). The Emergence of Modern Turkey. London.

Mamoni, K. (1983). Union Organisation of the Greek Populace in Asia Minor. Press Release of the Historical and Ethnological Company of Greece, 25, 63-114.

Mamoni, K. (1983). The Greek Philological Cyrcle in Konstaninople. Venizelos and the Asia Minor Campaign. Press Release the Centre for Asia Minor Studies, 4, 277-300.

Memorandum Concerning the Rights and Advercities for the Residences in Asia Minor and Thrace. (1918). Athens.

Morgenthau, H. (1929). I was send to Athens. New York.

Night Wire, A. P. (1918, June 6). Turks Slaughter Greeks, Sell Women to Slavery. The Los Angeles Times. Los Angeles.

Notaras, M. I. (1972). To Ionia, Aiolia and Lidia. Athens. 
Panayotopoulos, A. (1983). On the Economic Activities of the Anatolian Greeks, mid 19th Century to early 20th. Press Release The Centre for Asia Minor Studies, 4, 87-128.

Persecutions of the Greek Population in Turkey since the Beginning of the European War-According to Official Reports of Hellenic Diplomatic and Consular Agents, Greek Ministry for Foreign Affairs. 1918. London.

Sideris, G. (1990). History of the New Greek Theatre 1794-1908. Museum and Centre for the Study of Greek Theatre. Athens.

Soldatos, C. (1989-1991). The Educational and Spiritual Movement of the Greeks in Asia Minor (1800-1922). Athens.

Soldatos, X. (1998, May 3). Education in Smyrna. Kathimerini (pp. 3-6). Athens

Solomonidis, C. (1954). Theatre in Smyrna 1657-1922. Athens.

Solomonidis, C. (1959). Journalism in Smyrna. Athens.

Stavrou, T. (1967). The Greek Philological Cyrcle in Konstaninople. The Ministry for Education of the Enslaved Greeks. Athens.

Taner, A. (2007). A Dispeakable Act. The Armenian Genocide and the Matter of Turkish Responsibility, Athens.

Alexandris, A. (2000).The Archive of the Ethno Martyr from Smyrna Chrisostomos. Athens.

Turner, B. (1993). Contemporary problems in the theory of citizenship. Citizenship and Social Theory, 1-18. London. Sage.

Urry, J. (1997, May). Globalisation and the social. Paper presented to LSE/Oxford Conference on The Construction of Social Reality. Oxford.

Urry, J. (1998, July). Globalisation and Citizenship Paper given to World Congress of Sociology. Montreal.

Vakalopoulos, K. (1998). Persecutions and Genocide of the Thrasian Greeks. First Uprooting 1908-1917. Thessaloniki.

Veremis, T. (1998). History of the Greek-turkish Relations 1453-1998. Athens, ELIAMEP.

Waters, M. (1995). Globalization. London, Routledge.

Yuval-Davis, N. (1997). National Spaces and Collective Identities: Border, Boundaries, Citizenship and Gender Relations. Inaugural Lecture, University of Greenwich.

Zürcher, E. (1984). The Unionist Factor. The Role of Union and Progress in the Turkish National Movement 1905-1926. ZWO.

Note

Note 1. For the key processes of so-called globalisation Appadurai, 1990: 295-310; Brunn \& Leinbach (eds). 1991; Gilroy, 1993; Lash \& Urry 1994; Waters 1995; Featherstone, Lash \& Robertson (eds) 1995; Albrow, 1996; Castells, 1996; Cerny ,1997; First, there is the development of new machines and technologies which dramatically shrink time-space and in part transcend societal control and regulation. These include fibre-optic cables, jet planes, audiovisual transmissions, digital TV, computer networks including the internet, satellites, credit cards, faxes, electronic point-of-sale terminals, portable phones, electronic stock exchanges, high speed trains and virtual reality. There are also large increases in nuclear, chemical and conventional military technologies and weapons, as well as new waste products and health risks, which necessitate inter-societal regulation to ensure personal and national security.

\section{Appendix}

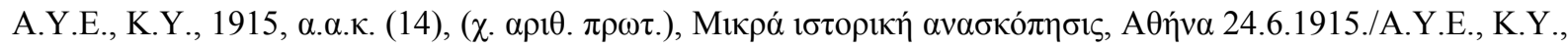

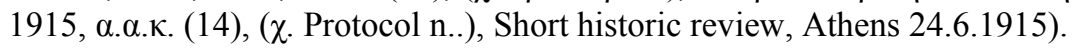

A.Y.E, K.Y., 1914, A/21 घ', $\sigma \tau^{\prime}$, protocol n. 539, Kapsabellis addresses Pana, Smyrna 21.2.1914.

A.Y.E., K.Y., 1914, A/21 a', protocol n. 14687, 5.1914.

A.Y.E., K.Y., 1914, A/21 a’, protocol n. 58, Tserepis addresses Strait, Aivali 16.3.1914.

A.Y.E., K.Y., A/21/ ๆ’ (without protocol n.), Chrisostomos addresses Kapsabellis, Smirna 26.5.1914.

Affari Politici, Turchia 1919-1930, Pacco 1666, N. 1817/203, Athens 5.9.1917. 
Wien, HHStA, PA, XXXVIII, Karton 349, Konsulate 1910, Smyrna, No 67, Austrian consul in Smyrna addressing count Alois Grafen von Aehrenthal, Smirna 14.10.1910.

Wien, HHStA, PA, XXXVIII, Karton 369, Konsulate 1916, Smyrna, No 28/P, Austrian consul in Smyrna addressing the minister for foreign affairs baron St. Buriàn, Smirna 18.4.1916.

«900.000 Greeks Killed», The New York Times, New York 3.12.1918.

«Germans Inspired Turkish Atrocities against Greeks», The New York Times, 19.9.1918.

«Persecution of Greeks Turco-German Plan», The Scotsman, 15.7.1915.

«Turkish Cruelty bared by Greeks», The New York Times, New York 16.6.1918. 